\title{
Enlightened Nonsense Ten Short Performance Films
}

Deirdre Logue

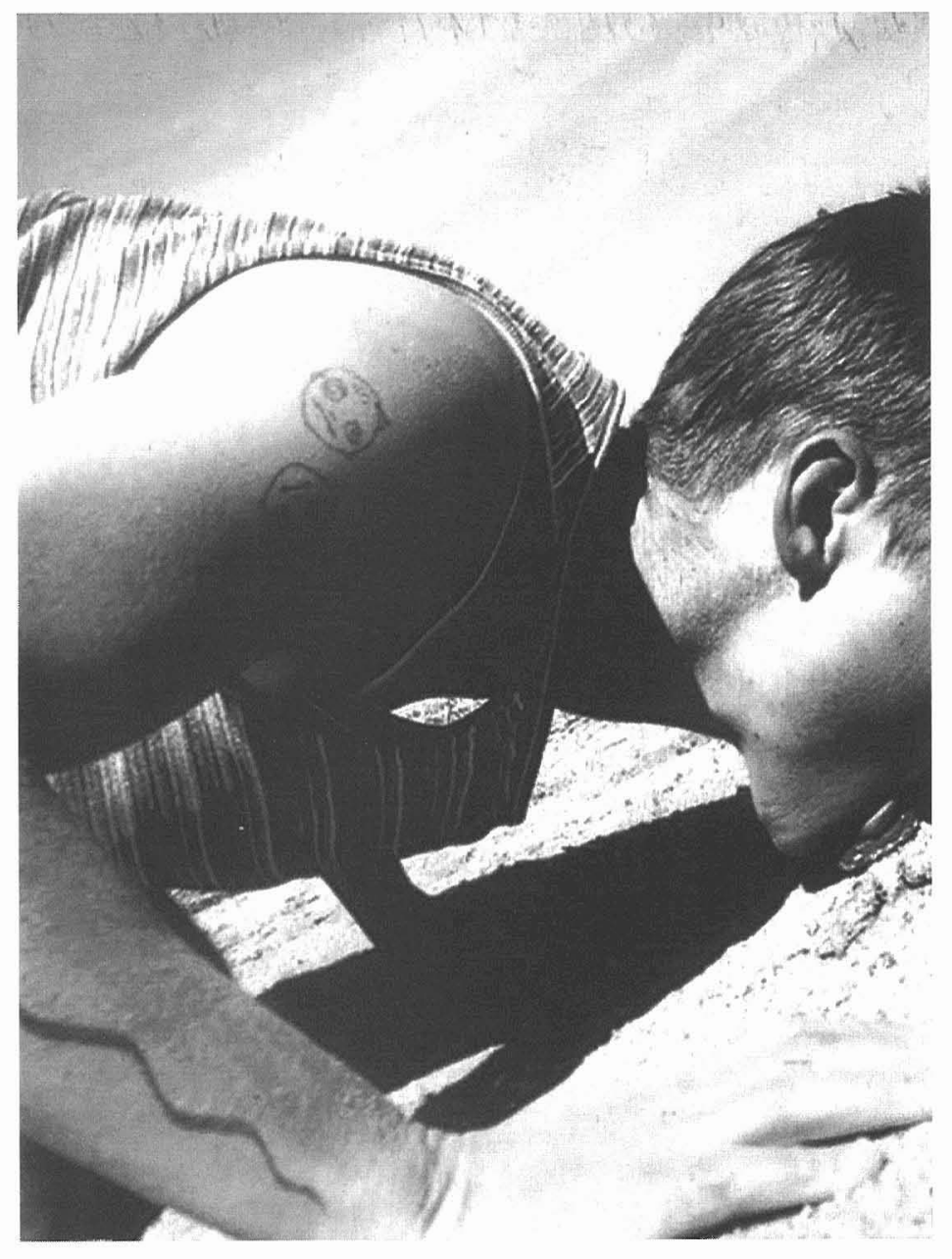

Road Trip, 2000, still, hand pressed, hand printed film 


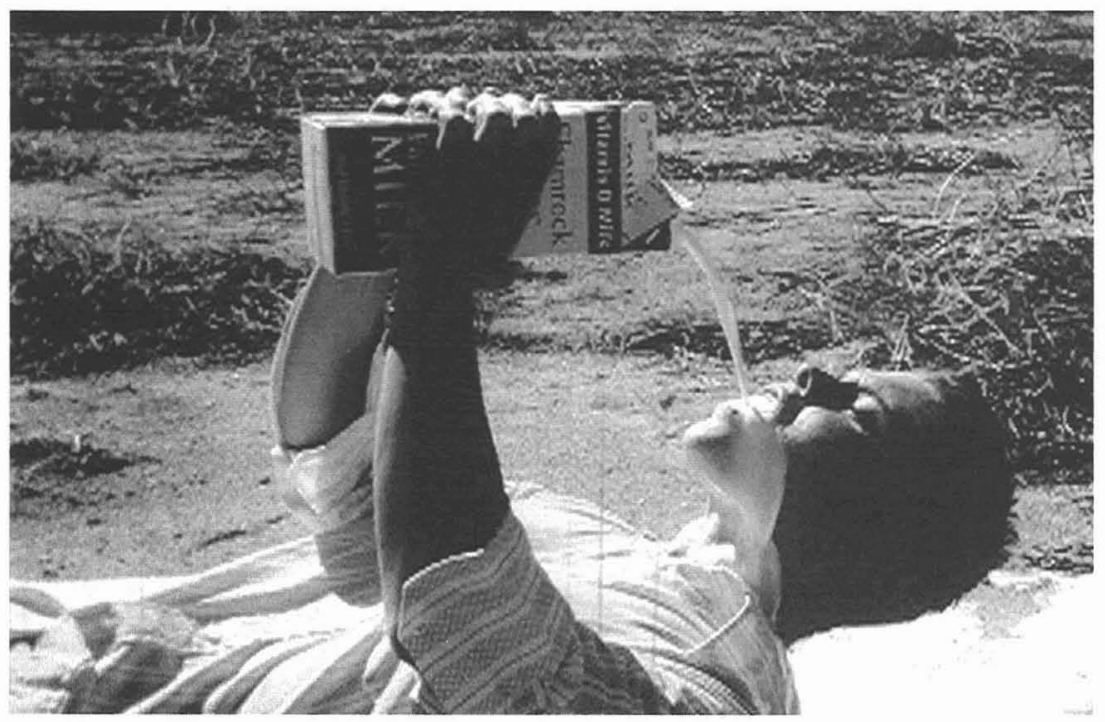

Milk and Cream, 2000, still, hand pressed, hand printed film

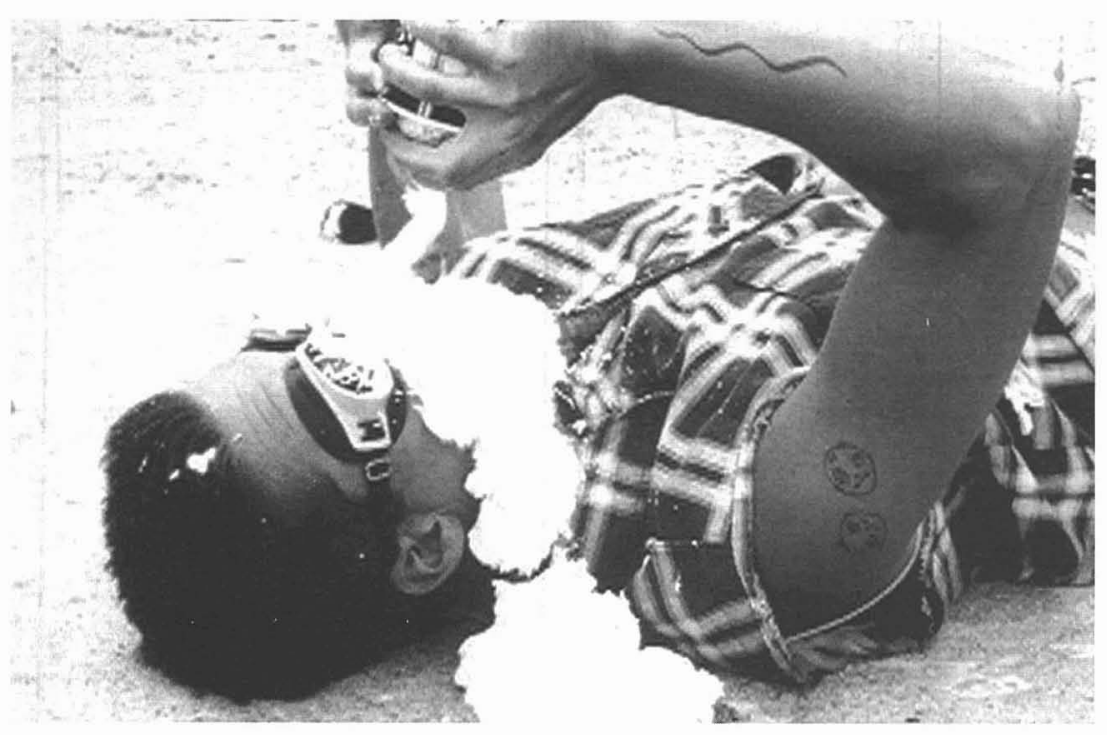

Milk and Cream, 2000, still, hand pressed, hand printed film 